\title{
El cómic y el arte pop
}

\author{
Martha Patricia Trejo Cerón
}

\section{Resumen}

En este video hablo sobre las características principales del Arte Pop, usando al comic como centro visual como lo hizo en su momento esta corriente artística de trasmitir un mensaje y llegar con más impacto a la sociedad, en este caso lo uso para captar de una forma más efectiva la atención de mis alumnos de un tema teórico, haciendo el material atractivo y dinámico, con el cual se puedan identificar, reflexionar y comprender lo más representativo del tema.

Palabras clave: Arte Pop, comic, video, superhéroes, pandemia.

\section{COMIC AND POP ART}

\begin{abstract}
In this video I talk about the main characteristics of Pop Art, using the comic as a visual center as this artistic trend did at the time of transmitting a message and reaching society with more impact, in this case I use it to capture in a way more effective the attention of my students of a theoretical topic, making the material attractive and dynamic, with which they can identify, reflect and understand the most representative of the topic.
\end{abstract}

Keywords: Pop art, comic, video, superheros, pandemic.

Recepción: 04/02/2021. Aprobación: 18/03/2021. Dol: http://doi.org/10.22201/cuaieed.16076079e.2021.22.3.14 
"El cómic y el arte pop" Martha Patricia Trejo Cerón Vol. 22, Núm. 3, mayo-junio 2021 Revista Digital Universitaria

\section{Martha Patricia Trejo Cerón}

$$
\begin{array}{r}
\text { dgpattytrejo@gmail.com } \\
\text { orcid.org/0000-0001-6905-630X } \\
\text { Instagram: @dg_patcrane }
\end{array}
$$

Es licenciada en Diseño Gráfico. Cuenta con una Especialidad en Mercadotecnia por la Universidad Tecnológica de México. Profesora Definitiva de Asignatura A, con 15 años de antigüedad en las asignaturas de Taller de Expresión Gráfica y Taller de Diseño Ambiental del ccH-Naucalpan. Ha tomado diversos cursos de actuación disciplinaria, así como diplomados en docencia y nuevas tecnologías.

Ha incursionado en Proyectos DGAPA-INFOCAB-PAPPIT. Ha presentado ponencias en diversos congresos relacionados con la identidad afromexicana y la danza de los diablos. Ha sido panelista en dos programas de Mirador Universitario (CUAED, UNAM). Formó parte del Seminario Permanente Identidad(es) en Perspectiva Multidisciplinaria. Ha participado como ponente en las dos Jornadas de Artes Visuales del сCH Naucalpan. Es coautora de los libros Identidad Cultural y sus Componentes. Hacia la Identificación de Categorías Empíricas con fines Estadísticos, en el Instituto de Investigaciones Antropológicas de la unam y Cultura, Poder y Desarrollo: Territorios en Movimiento, de Universidad de Guanajuato.

Como ilustradora, ha colaborado con Delfos, revista de filosofía del cch Naucalpan. En el mismo plantel actualmente es la Coordinadora del Seminario interdisciplinario para fortalecer en los estudiantes la formación ciudadana en cuanto a equidad e igualdad de género y respeto a la diversidad sexual (SEIDIG). 
Lo que me encanta del arte es que, en particular a través de sus diferentes manifestaciones artísticas y técnicas de pintura, podemos representar cualquier tema y época. De esta manera, se puede llegar a las personas; con un mensaje en específico se logra compartir un conocimiento o concientizar sobre algún hecho actual que afecte a la sociedad y se despierta su interés, en especial el de las nuevas generaciones, para que se involucren en lo que sucede en el mundo.

Es por ello que durante el curso "Herramientas para la comunicación docente. Entre lo oral y lo digital", impartido por la Coordinación de Universidad Abierta, Innovación Educativa y Educación a Distancia (CUAIEED), realicé un video como proyecto final, sobre el arte pop enfocado al cómic, que es algo que a través del tiempo no pasa de moda, sigue vigente y captura la atención de los jóvenes. Además, es un material que puedo usar como introducción, para esta corriente artística, en mis clases de Taller de Expresión Gráfica, al explicar sus características principales y mostrar imágenes con las que se identifiquen mis alumnos, con lo que se captura su atención y se logra desarrollar de manera más amplia el tema en clase.

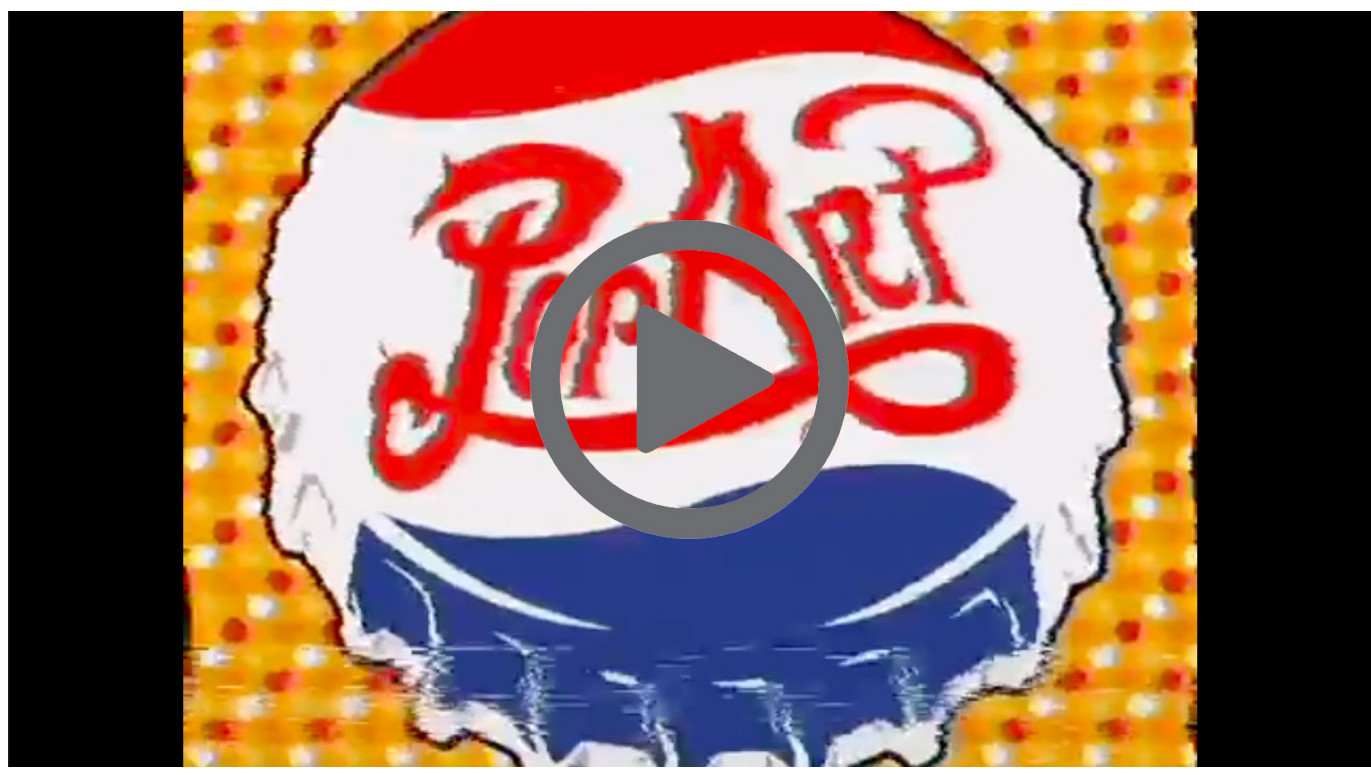

Para realizar dicho video, busqué imágenes de diferentes superhéroes con los que las nuevas generaciones se identifican. En los temas musicales, el primero fue la introducción de la serie de Batman de los años sesenta, pues en su opening manejaban partes de comic. La segunda canción fue "Take on me", del grupo A-HA, ya que su video se desarrolla dentro de una historieta a blanco y negro, y mi objetivo es que todo tuviera relación con el tema del cómic, además de que sea atractivo y deje no sólo un conocimiento, sino también un mensaje. Por ello, al final de mi video, use imágenes de superhéroes con cubrebocas, para dar a entender que, a pesar de sus poderes, no son inmunes a lo que vivimos en la actualidad a nivel mundial. Así, por la pandemia todos debemos tomar precauciones. 
"El cómic y el arte pop" Martha Patricia Trejo Cerón

Cuando expuse este material en mis clases, noté a mis alumnos muy atentos, divertidos y disfrutando de la música. Yo realmente quedé satisfecha, pero no había imaginado el alcance que tendría el video; no sólo porque desperté su interés en un tema académico, sino porque de verdad hicieron una reflexión con el tema de la pandemia, hablaron de sus experiencias de haber contraído coronavirus, ellos o algún integrante de su familia. Hubo los que lamentablemente tuvieron pérdidas de familiares o amigos y los que daban gracias porque salieron adelante. Al final, el video contribuyó a que sacaran esa carga sobre el tema, ya que muchas veces ellos sólo buscan que alguien los escuche, los apoye, sentir que no están solos. Así, considero que de alguna forma, sin buscarlo, los apoyé. Es por eso que este proyecto me deja una muy grata experiencia y mucho aprendizaje, que me motivan a seguir desarrollando materiales para mis clases.

\section{Sitios de interés}

- Arte pop: características, artistas y obras claves

- El cómic del arte pop

- ¿Qué es el POP ART? características e importancia para la sociedad [video]

- How to make a Pop Art Inspired Comic Book Onomatopoeia

\section{Cómo CITAR ESTE ARTículo}

* Trejo Cerón, Martha Patricia. (2021, mayo-junio). El cómic y el arte pop. Revista Digital Universitaria (RDU), 22(3). http://doi.org/10.22201/cuaieed.16076079e.2021.22.3.14 